\title{
Stochastic Modeling of Stock Price Behavior on Ghana Stock Exchange
}

\section{Osei Antwi}

Mathematics \& Statistics Department, Accra Technical University, Accra, Ghana

Email address:

oseiantwi@yahoo.co.uk

\section{To cite this article:}

Osei Antwi. Stochastic Modeling of Stock Price Behavior on Ghana Stock Exchange International Journal of Systems Science and Applied Mathematics. Vol. 2, No. 6, 2017, pp. 116-125. doi: 10.11648/j.ijssam.20170206.12

Received: September 12, 2017; Accepted: September 27, 2017; Published: November 14, 2017

\begin{abstract}
This paper analyzes stock price behaviour on Ghana Stock Exchange (GSE) and develops a stochastic model to predict the behaviour of stock prices on the exchange using Monte Carlo simulations. The first part looks at the various justifications and models that have been put forward to explain stock behaviour and its distribution elsewhere. It traces the foundations of the use of stochastic process as a means of predicting stock price behaviour from Louis Bachelier normality assumption to the works of Samuelson's lognormal supposition through to the doctoral thesis of Fama French in which he premised the behaviour of stock price to the idea of a random walk. We subsequently apply the Geometric Brownian Motion formulation to simulate stock price behaviour for all listed stocks on the GSE for the coming year (2015) using historical volatility and mean returns of the previous year (2014). The results find increasing evidence that the stochastic model consistently predict the stock price behaviour on the exchange in more than $80 \%$ of the listed stocks.
\end{abstract}

Keywords: Stock Price, Geometric Brownian Motion, Stock return, Stock Volatility, Monte Carlo Simulation

\section{Introduction}

The impact of stock market behaviour on many economies especially in emerging markets of Africa, South America and Asia has become more recognized in recent years. Market performance in particular has attracted a lot of attention from traders, regulators, exchange officials as well as academics. However, existing literature and studies into this subject especially on predictive analysis is limited in these regimes. For example, mathematical models required to estimate and predict the behaviour of stocks prices and its dynamics on the Ghana Stock Exchange (GSE) are virtually nonexistent. Existing literature and models are mainly based on deterministic evaluation of market variables using mostly past data. It means that most investors trading on the exchange hardly have any means of forecasting the behaviour of stocks and predicting the returns on their investments. This paper will provide the necessary literature and mathematical background that will enable investors, academics and other interested parties to study and predict stock price behaviour on the exchange. The theoretical background would also provide a sufficient link of knowledge from mathematics to researchers, financial engineers and economist and develop new ways to enhance risk control and improve profitability of investments. The study will thus address the following issues:

1. Develop a model to forecast stocks price behaviour on the exchange

2. Test the model using data from Ghana Stock Exchange

3. Develop probability distribution functions to predict the future behaviour of stocks listed on the exchange

The various approaches to Stock Price Modelling

Robert Brown (1828), the Scottish botanist, while looking through a microscope at particles trapped in cavities in pollen grains, noticed that the grains of pollen suspended in water had a rapid oscillatory motion. Although Brown published his observations, he was not able to determine the mechanisms that caused this motion. Einstein (1905) published his classic paper in which he explained in precise detail how the motion that Brown had observed was a result of the pollen being moved by individual water molecules. This phenomenon is now known as Brownian motion. The precise definition of Brownian motion is given later in the text but Wiener (1923) gave a formal mathematical theory on the subject and thus it is sometimes referred to as the Wiener process. 
The foundations for the use of stochastic process as a means of predicting and forecasting stock price behaviour were laid down by Bachelier (1900) who developed the first mathematical model of a stock's price and tested the model by using it to price futures and options. Bachelier assumed stock price dynamics follows a Brownian motion with no time-value of money. Kendall (1953), Roberts (1959) and Samuelson (1965) modified Bachelier's model so that the stock price followed a log-normal distribution. Samuelson model is now known as Geometric Brownian Motion (GBM) Fama (1965) premised the behaviour of a stock price to the idea of a random walk. The key assumption of random walk is that stock prices reflect information regarding the business. If information available makes investors believe the business/company will prosper, confidence in the stock's value will soar and demand for the stock will go up, increasing the stock's price. On the otherhand, if information available makes investors believe the fortunes of the business will decline, investor confidence in the stock will diminish and demand for the stock will go down, decreasing the stock price. Because information arrives randomly, stock prices have to fluctuate randomly leading to the random walk idea. If the flow of information is unimpeded and information is immediately reflected in stock prices, then tomorrow's price change will reflect only tomorrow's news and will be independent of the price changes today.

Fama defined three levels at which information is absorbed by an "efficient market", a market which he defined as where there are large number of rational profit-maximizers actively competing, with each trying to predict future market values of individual securities, and where important current information is almost freely available to all participants. Fama defined three levels at which information is absorbed by the market as the weak form, the semi-strong and the strong from of market efficiency. He called his ideas Efficient Market Hypothesis (EMH).

Fama (1970) reviewed and empirically tested the three forms of EMH. He first tested the weak form in which prices adjusts when the only available information is the historical price of stock. He also tested the semi-strong from in which the main concern was whether prices efficiently adjust to other information that is obviously publicly available such as announcements of annual earnings, stock splits, takeovers, mergers, etc. Finally, he tested the strong form in which he observed price behaviour when investors or groups have monopolistic access to any information relevant to the stock price. In this landmark empirical analysis of stock market prices Fama concluded that stock prices follow a random walk.

Meanwhile other researches countered Fama's ideas. Cootner (1964) had earlier concluded that the stock market is not a random walk Beja (1977) showed that the efficiency of a real market is impossible. Grossman and Stiglitz (1980) showed that it is impossible for a market to be perfectly informationally efficient. Because information is costly, prices cannot perfectly reflect the information which is available, since if it does so, investors who spent resources on obtaining and analyzing it would receive no compensation. Summers (1986) argued that many statistical tests of market efficiency have very low power in discriminating against plausible forms of inefficiency. French and Roll (1986) found that asset prices are much more volatile during exchange trading hours than during nontrading hours and deduced that this is due to trading on private information where the market generates its own news. Lo and MacKinlay (1988) strongly rejected the random walk hypothesis for weekly stock market returns using the variance-ratio test. Poterba and Summers (1988) showed that stock returns show positive autocorrelation over short periods and negative autocorrelation over longer horizons. In effect, the degree of market efficiency is controversial and many believe that one can beat the market in a short period of time. However, EMH has provided the theoretical basis for much of the research and most empirical studies on predicting stock price behaviour.

In Ghana studies into stocks has mainly concentrated on assessing stock parameters rather than the actual behaviour of the stocks. Harvey, et al. (2008), looked at the relationship between the Ghana stock market and foreign exchange market to determine whether movements in exchange rates have an effect on stock market in Ghana. They used the Exponential Generalised Autoregressive Conditional Heteroskedascity (EGARCH) model in establishing the relationship between exchange rate volatility and stock market volatility. Antwi, et. al. (2012), compared risk and returns characteristics of stock exchange traded shares and treasury bills in Ghana using statistical measures such as average annual rate of return (nominal and real), standard deviation and coefficient of variation. Osei, et, al. (2005), employed a Vector Auto-regressive Model to investigate the impact of stock market on economic growth in Ghana. His empirical results indicated that stock market development causes economic growth in Ghana and the causation is unidirectional from stock market to economic growth.

Recently, other methods have emerged to model and predict stock price behaviour. Landauskas, (2011) presented an approach in which stock prices are modeled using Markov Chain Monte Carlo (MCMC) sampling from piecewiseuniform distribution. The use of neural networks in stock price prediction has also been examined. Yoon (1991), Refenes, et. al. (1994) predicted stock price performance using neural network approach. Kryzanowski, et al. (1993), Azoff (1994), Neenwi, et. al. (2013) forecasted stock prices using artificial neural networks. Estember and Maraña compared the effectiveness and accuracy of the Geometric Brownian motion to the Artificial Neural Network method on stocks listed on the Philippine Stock Exchange. It was observed that average parentage error of the Geometric Brownian Motion method was $6.21 \%$ or an accuracy of 93.79\% while the Artificial Neural network method generated an average percentage error of $8.83 \%$ for the threeyear period or an accuracy of $91.17 \%$. This showed the Geometric Brownian Motion to be a better model in predicting stock price behaviour than Artificial Neural network. 


\section{Method}

Any variable whose value changes over time in an uncertain way is said to follow a stochastic process. The notion of stochastic processes is very important in mathematical finance as it can be used to model various phenomena where the quantity or the variable varies continuously through time. Many processes are often modelled by a stochastic process and is an umbrella term for any collection of random variables $\{X(t)\}$ depending on time $t$. Time can be discrete, for example, $t=0,1,2, \ldots$ or continuous, $t \geq 0$.

\subsection{The Brownian Motion Process}

The Brownian motion $B(t)$ is used to capture the uncertainty in the future behaviour of a stochastic process and has the following properties.

1. (Independence of increments) $B(t)-B(s)$, for $t>s$, is independent of the past

2. (Normal increments) $B(t)-B(s)$ has Normal distribution with mean 0 and variance $t-s$. if $s=0$ then $B(t)-B(0) \sim N(0, t)$.

3. (Continuity of paths) $B(t), t \geq 0$ are continuous functions of $t$.

Louis Bachelier used Brownian motion to model the stock price. In a differential form, the Bachelier model can be written as

$$
d S(t)=\mu d t+\sigma d B(t)
$$

Where $S(t)$ is the stock price, $B(t)$ is the Brownian motion or Wiener process, $\mu$ is the return on the stock price, $\sigma$ is the volatility of the stock price. Equation 1 is called arithmetic Brownian motion.

The solution to Equation 1 is

$$
S(t)=S(0)+\mu t+\sigma B(t)
$$

The only weakness of the model is that stock prices can be negative which is contrary to reality.

\subsubsection{Geometric Brownian Motion}

Let denote the stock price process by $S(t)$, the return on the stock by $\mu$, then the return of the stock price is

$$
\text { Return }=\frac{\text { change in price }}{\text { original price }}
$$

Consider a small subsequent time interval $(t, t+\Delta t)$ during which $S(t)$ becomes $S(t+\Delta t)=S(t)+\Delta S(t)$. The return on the stock price between time $t$ and $t+\Delta t$ is given by

$$
\text { Return }=\frac{S(t+\Delta t)-S(t)}{S(t)}=\frac{\Delta S(t)}{S(t)}
$$

This is the return of the stock price. We model this return of the stock's price as akin to a two asset portfolio consisting of a non-risky asset such as a bond and a risky asset such as a derivative. If the return of the non-risky asset is $\mu$ then in a small time interval $d t$ the return would be $\mu d t$. The return of the risky asset however is uncertain and this uncertainty or randomness is captured by the Brownian motion $B(t)$. In an infinitesimal time interval $\Delta t$ the return of the asset is given by

$$
\begin{aligned}
& \frac{\Delta S(t)}{S(t)}=\mu \Delta t+\sigma d B(t) \\
& \frac{d S(t)}{S(t)}=\mu d t+\sigma d B(t)
\end{aligned}
$$

or

$$
d S(t)=\mu S(t) d t+\sigma S(t) d B(t)
$$

where $\sigma$ is the standard deviation of the stock return and depends on the random change in the asset price to external effects such as unexpected news. Equation 4 is referred to as the Geometric Brownian motion. In integral form

$$
S(t)=\mu \int_{0}^{t} S(u) d u+\sigma \int_{0}^{t} S(u) d B(u)
$$

$S(t)$ is said to be an Ito process.

\subsubsection{Solution to Geometric Brownian Motion}

A unique solution to Equation 4 is obtained as follows: Let

$$
f(t)=\ln S(t), \text { then } f^{\prime}(t)=\frac{1}{s(t)} \text { and } f^{\prime \prime}(S(t))=-\frac{1}{s(t)^{2}}
$$

By Ito formula for Ito process

$$
d(\operatorname{InS}(t))=f^{\prime} d S(t)+\frac{1}{2} f^{\prime \prime} \sigma^{2}(t) d t
$$

Hence

$$
\begin{gathered}
d(\operatorname{In} S(t))=\frac{1}{S(t)} d S(t)+\frac{1}{2}\left(-\frac{1}{S(t)^{2}}\right) \sigma^{2}(t) S(t)^{2} d t \\
d(\operatorname{In} S(t))=\frac{1}{S(t)}(\mu S(t) d t+\sigma S(t) d B(t))-\frac{1}{2} \sigma^{2} d t \\
d(\operatorname{In} S(t))=\left(\mu-\frac{1}{2} \sigma^{2}\right) d t+\sigma d B(t)
\end{gathered}
$$

Integrating both sides gives

$$
\begin{gathered}
\operatorname{In} S(t)=\operatorname{InS}(0)+\left(\mu-\frac{1}{2} \sigma^{2}\right) t+\sigma B(t) \\
\operatorname{In}\left(\frac{S(t)}{S(0)}\right)=\mu-\frac{\sigma^{2}}{2}+\sigma B(t) \\
\frac{S(t)}{S(0)}=e^{\left(\mu-\frac{\sigma^{2}}{2}\right) t+\sigma B(t)} \\
S(t)=S(0) e^{\left(\mu-\frac{1}{2} \sigma^{2}\right) t+\sigma B(t)}
\end{gathered}
$$

or

$$
S(t)=S(0) \exp \left\{\left(\mu-\frac{\sigma^{2}}{2}\right) t+\sigma d B(t)\right\}
$$

\subsection{Simulating a Stock Price Using GBM}

From its properties, the increment in Brownian motion $B(t+1)-B(t)$ is normally distributed with mean 0 and variance 1 . Hence it follows that the probability distribution of the change in stock value from now to the coming year is standard normally distributed with mean 0 and variance 1 . Similarly, the probability distribution of the change in stock value between year 1 and year 2 is also normally distributed 
with mean 0 and variance 1 . Thus, the probability distribution of change in stock value in two years is the sum of the two normal distributions each with mean 0 and variance 1 . This means that in two years the probability distribution of change in the stock price is normally distributed with mean $\mu=0+0=0$ and variance $\sigma^{2}=1+$ $1=2$. Hence in two years the probability distribution of the change in $S(t)$ is normally distributed with mean 0 and standard deviation $\sqrt{2}$. That is, $S(t)-S(0) \sim N(0, \sqrt{2})$. More generally in $T$ years the probability distribution of the stock price is $N(0, \sqrt{T})$. Hence in a short time period the change in stock price is normally distributed with mean 0 and standard deviation $\sqrt{\Delta t}$. That is $S(t) \sim N(0, \sqrt{\Delta t})$. Now let $\xi(t)$ denote the randomness captured by the Brownian motion $B(t) . \xi(t)$ is known as the White Noise process and is defined as the derivative of the Brownian motion $B(t)$ such that

$$
\xi(t)=\frac{d B(t)}{d t}=B^{\prime}(t)
$$

It follows that $d B(t)=\xi(t) d t$

From Equation 4

$$
d S(t)=\mu S(t) d t+\sigma S(t) \xi(t) d t
$$

In discrete form, in the short time period $\Delta t$, Equation 7 can be written as

$$
\Delta S(t)=\mu S(t) \Delta t+\sigma S(t) \xi(t) \sqrt{\Delta t}
$$

Equation 8 will be used to simulate future stock prices for stocks listed on the exchange. A Monte Carlo simulation of the stock price will be based on sampling random outcomes for the process. A price path for a stock can be simulated by sampling repeatedly for $\xi(t)$ from $N(0,1)$ and substituting in Equation 8. The expression $=$ RAND ( ) in Excel produces a random sample between 0 and 1 . The inverse cumulative normal distribution is NORMSINV. In Excel, random samples are generated from standard normal distribution and the inverse is obtained using NORMSINV(RAND( )).

\subsection{Computing the Mean and Volatilities}

The modeling begins by estimating the historical volatility and the return of the stock price by observing the daily stock price (closing price) of the each stock for the immediate past year. A one year data (2014) from the Ghana Stock Exchange is used to compute the daily returns of each stock. From this the average daily return is determined. The standard deviation of the daily stock price returns (volatility) of each stock is also computed. Knowing $\mu$ and $\sigma$ allow for the simulation of the daily price paths of individual stocks for the coming year (2015) in the time interval of $\left(\frac{1}{\text { trading days }}\right)$. Assuming that there are no price changes from the last trading day of 2014 and the first trading day of 2015 the initial stock price $S(0)$ for the simulation is the closing price for the last trading day of 2014. The procedure for the Monte Carlo simulation process can thus be summarized as follows:

1. Compute the daily return of a stock as follows

$$
\mu_{i}=\ln \left(\frac{s\left(t_{i}\right)}{s\left(t_{i-1}\right)}\right)
$$

and mean stock price return as

$$
\hat{\mu}_{i}=\frac{1}{n} \sum_{i=1}^{n} \ln \left(\frac{S\left(t_{i}\right)}{S\left(t_{i-1}\right)}\right)
$$

Find standard deviation (volatility) of each stock

$$
S(t)=\sqrt{\frac{1}{n-1} \sum_{i=1}^{n} \mu^{2}-\frac{1}{n(n-1)}\left(\sum_{i=1}^{n} \mu_{i}\right)^{2}}
$$

2. Determine the time interval $\Delta t$, where $\Delta t=\frac{1}{\text { trading days }}$

3. Simulate the price path using the equation

$$
\operatorname{In} \Delta S(t)=\mu S(t) \Delta t+\sigma S(t) \xi(t) \sqrt{\Delta t}
$$

For each stock, several price paths are simulated by generating different set of random numbers. This captures different realizations of price paths from which the mean is taken as the realized price path of the stock. By central limit

\begin{tabular}{|c|c|c|c|c|c|c|c|c|c|}
\hline $\begin{array}{l}\text { Name of } \\
\text { Stock }\end{array}$ & $\begin{array}{l}\text { African } \\
\text { Champion } \\
\text { Ltd. }\end{array}$ & $\begin{array}{l}\text { AngloGold } \\
\text { Ashanti Ltd. }\end{array}$ & $\begin{array}{l}\text { Aluworks } \\
\text { Limited }\end{array}$ & $\begin{array}{l}\text { Ayrton Drug } \\
\text { Man. Ltd. }\end{array}$ & $\begin{array}{l}\text { Benso Oil } \\
\text { Palm Plantn }\end{array}$ & $\begin{array}{l}\text { Cal Bank } \\
\text { Ltd. }\end{array}$ & $\begin{array}{l}\text { Clydestone } \\
\text { Ghana Ltd. }\end{array}$ & $\begin{array}{l}\text { Camelot } \\
\text { Ghana Ltd. }\end{array}$ & $\begin{array}{l}\text { Cocoa } \\
\text { Processing } \\
\text { Co. Ltd. }\end{array}$ \\
\hline $\begin{array}{l}\text { Mean daily } \\
\text { return } \mu\end{array}$ & -0.00024579 & 0 & -0.000190044 & $7.12753 \mathrm{E}-05$ & 7.12753E-05 & $6.38786 \mathrm{E}-06$ & $3.01065 \mathrm{E}-06$ & -0.000105944 & 0.000394695 \\
\hline $\begin{array}{l}\text { Standard } \\
\text { deviation } \sigma\end{array}$ & 0.001105707 & 0 & 0.001948128 & 0.000476401 & 0.000476401 & 0.000492955 & $3.68 \mathrm{E}-05$ & 0.000377595 & 0.00332083 \\
\hline $\begin{array}{l}\text { Name of } \\
\text { Stock }\end{array}$ & $\begin{array}{l}\text { Ecobank } \\
\text { Ghana Ltd. }\end{array}$ & $\begin{array}{l}\text { Enterprise } \\
\text { Group Ltd. }\end{array}$ & $\begin{array}{l}\text { Ecobank } \\
\text { Transnational } \\
\text { Inc. }\end{array}$ & $\begin{array}{l}\text { Fan Milk } \\
\text { Ltd. }\end{array}$ & $\begin{array}{l}\text { Ghana } \\
\text { Commercial } \\
\text { Bank Ltd. }\end{array}$ & $\begin{array}{l}\text { Guinness } \\
\text { Ghana } \\
\text { Breweries } \\
\text { Ltd. }\end{array}$ & $\begin{array}{l}\text { Ghana Oil } \\
\text { Company } \\
\text { Limited }\end{array}$ & $\begin{array}{l}\text { Golden Star } \\
\text { Resources Ltd. }\end{array}$ & $\begin{array}{l}\text { Golden Web } \\
\text { Ltd. }\end{array}$ \\
\hline $\begin{array}{l}\text { Mean daily } \\
\text { return } \mu\end{array}$ & $-3.5406 \mathrm{E}-06$ & $-2.4165 \mathrm{E}-05$ & 0.000159397 & $-2.4201 \mathrm{E}-06$ & $-1.42649 \mathrm{E}-05$ & -0.000194033 & $4.03683 \mathrm{E}-05$ & $-8.3161 \mathrm{E}-07$ & $-2.68262 \mathrm{E}-05$ \\
\hline $\begin{array}{l}\text { Standard } \\
\text { deviation } \sigma\end{array}$ & $3.69 \mathrm{E}-05$ & 0.00059431 & 0.000915661 & $3.03 \mathrm{E}-05$ & 0.00051762 & 0.000553149 & 0.000309014 & $1.98 \mathrm{E}-05$ & 0.000558668 \\
\hline
\end{tabular}
theorem it follows that this mean path is the price path of the stock.

\section{Results}

Table 1 gives the average daily returns and volatilities for the stocks listed on Ghana Stock Exchange for 2015.

Table 1. Mean returns and volatilities of traded stocks on GSE. 


\begin{tabular}{|c|c|c|c|c|c|c|c|c|c|}
\hline $\begin{array}{l}\text { Name of } \\
\text { Stock }\end{array}$ & $\begin{array}{l}\text { HFC Bank } \\
\text { Ghana Ltd. }\end{array}$ & $\begin{array}{l}\text { Mechanical } \\
\text { Lloyd Co. } \\
\text { Ltd. }\end{array}$ & $\begin{array}{l}\text { Pioneer } \\
\text { Kitchenware } \\
\text { Ltd. }\end{array}$ & $\begin{array}{l}\text { Produce } \\
\text { Buying } \\
\text { Company } \\
\text { Ltd. } \\
\end{array}$ & $\begin{array}{l}\text { PZ Cussons } \\
\text { Ghana Ltd. }\end{array}$ & $\begin{array}{l}\text { Standard } \\
\text { Chartered } \\
\text { Bank Ghana } \\
\text { Ltd. } \\
\end{array}$ & $\begin{array}{l}\text { SIC } \\
\text { Insurance } \\
\text { Company } \\
\text { Ltd. } \\
\end{array}$ & $\begin{array}{l}\text { Starwin } \\
\text { Products Ltd. }\end{array}$ & $\begin{array}{l}\text { Societe } \\
\text { Generale } \\
\text { Ghana } \\
\text { Limited } \\
\end{array}$ \\
\hline $\begin{array}{l}\text { Mean daily } \\
\text { return } \mu\end{array}$ & 0.00010824 & 0.00045135 & 0 & $-3.76499 \mathrm{E}-05$ & -0.000227264 & 0.000105183 & $-2.35313 \mathrm{E}-05$ & -0.000196679 & $4.03683 \mathrm{E}-05$ \\
\hline $\begin{array}{l}\text { Standard } \\
\text { deviation } \sigma\end{array}$ & 0.000612799 & 0.006412791 & 0 & 0.000808454 & 0.000463948 & 0.000325645 & 0.000596149 & 0.001934883 & 0.000309014 \\
\hline $\begin{array}{l}\text { Name of } \\
\text { Stock }\end{array}$ & $\begin{array}{l}\text { Sam Woode } \\
\text { Ltd. }\end{array}$ & $\begin{array}{l}\text { Trust Bank } \\
\text { Ghana Ltd. }\end{array}$ & $\begin{array}{l}\text { Total } \\
\text { Petroleum } \\
\text { Ghana Ltd. }\end{array}$ & $\begin{array}{l}\text { Transaction } \\
\text { Solutions } \\
\text { Ghana Ltd. }\end{array}$ & $\begin{array}{l}\text { Tullow Oil } \\
\text { Plc }\end{array}$ & $\begin{array}{l}\text { Unilever } \\
\text { Ghana Ltd. }\end{array}$ & $\begin{array}{l}\text { UT Bank } \\
\text { Ltd. }\end{array}$ & $\begin{array}{l}\text { Mega African } \\
\text { Capital Ltd. }\end{array}$ & \\
\hline $\begin{array}{l}\text { Mean daily } \\
\text { return } \mu\end{array}$ & 0.000117563 & $-7.73715 \mathrm{E}-05$ & -0.000108381 & 0 & $-5.76359 \mathrm{E}-05$ & $-9.11148 \mathrm{E}-05$ & $-4.12411 \mathrm{E}-05$ & $2.73272 \mathrm{E}-05$ & \\
\hline $\begin{array}{l}\text { Standard } \\
\text { deviation } \sigma\end{array}$ & 0.000861232 & 0.00064003 & 0.000667043 & 0 & 0.00063866 & 0.000493223 & 0.000974084 & 0.000424975 & \\
\hline
\end{tabular}

Table 2 shows the simulating results in Excel for a listed stock namely, CalBank. The stock has an annual return of 0.00233 , volatility of 0.179928 and has an initial stock price 1.01. The time interval is given by $\left(\frac{1}{\text { trading days }}\right)=\frac{1}{248}$. Although there were 248 trading days for 2015 the simulation procedure is shown for the only first 10 trading days.

Table 2. Simulation procedure for stock price path for CalBank.

\begin{tabular}{llll}
\hline $\begin{array}{l}\text { Trading } \\
\text { Day }\end{array}$ & $\begin{array}{l}\text { Stock Price } \\
\text { Path }\end{array}$ & $\begin{array}{l}\text { Random } \\
\text { Number }\end{array}$ & $\begin{array}{l}\text { Change in Stock } \\
\text { Price }(\Delta \boldsymbol{X})\end{array}$ \\
\hline 1 & 1.01 & 0.45363391 & -0.000112277 \\
2 & 1.0098877231 & 0.268281634 & -0.00063989 \\
3 & 1.0092478331 & 0.310094918 & -0.000510759 \\
4 & 1.0087370739 & 0.159504226 & -0.001036877 \\
\hline
\end{tabular}

\begin{tabular}{llll}
\hline $\begin{array}{l}\text { Trading } \\
\text { Day }\end{array}$ & $\begin{array}{l}\text { Stock Price } \\
\text { Path }\end{array}$ & $\begin{array}{l}\text { Random } \\
\text { Number }\end{array}$ & $\begin{array}{l}\text { Change in Stock } \\
\text { Price }(\Delta \boldsymbol{X})\end{array}$ \\
\hline 5 & 1.0077001968 & 0.068466358 & -0.001551041 \\
6 & 1.0061491557 & 0.673082346 & 0.000480268 \\
7 & 1.0066294234 & 0.871753109 & 0.001200148 \\
8 & 1.0078295717 & 0.317600814 & -0.000487823 \\
9 & 1.0073417488 & 0.619170971 & 0.000328535 \\
10 & 1.0076702835 & 0.549611466 & 0.000141137 \\
\hline
\end{tabular}

Annual return: $\mu=0.002331569$

Annual volatility: $\sigma=0.179928575$

Time interval: $\Delta t=\frac{1}{248}=0.0040486$

The realized Brownian motion paths for CalBank are shown in Figure $1(a, b, c d, e, f)$. Several price paths are generated but we show only a few here.

(a)

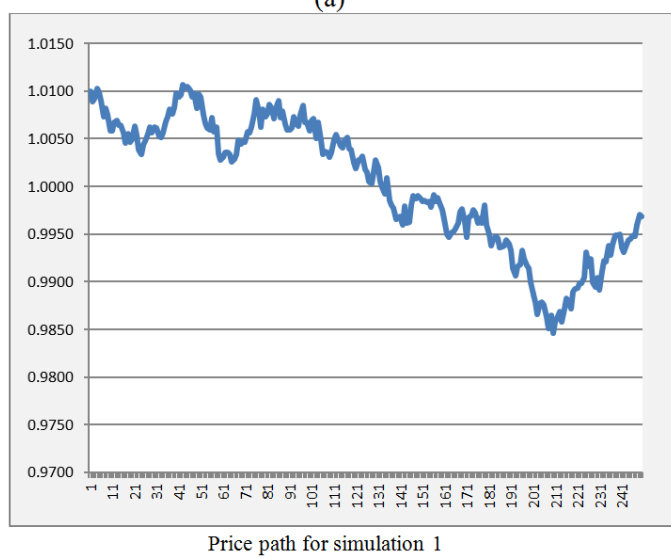

(c)

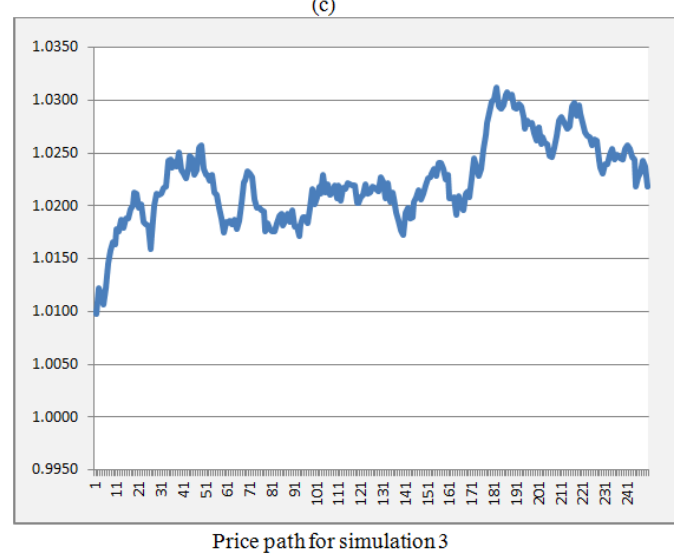

(b)

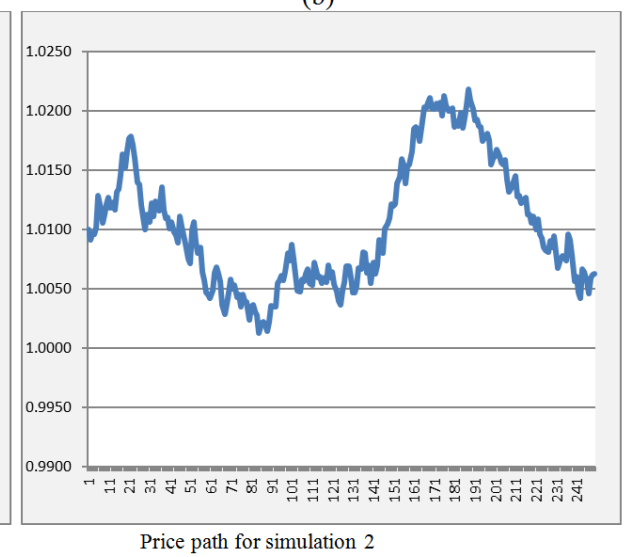

(d)

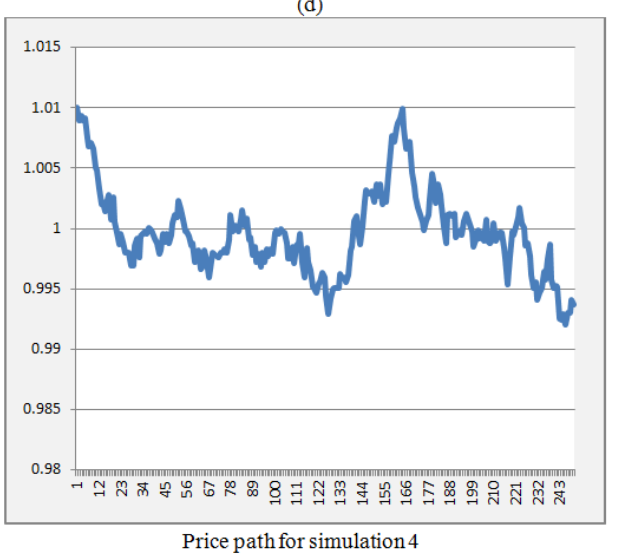


(e)

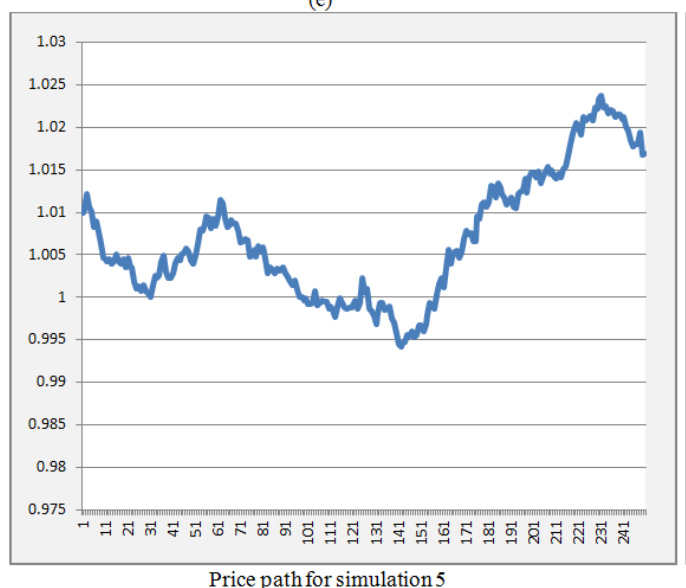

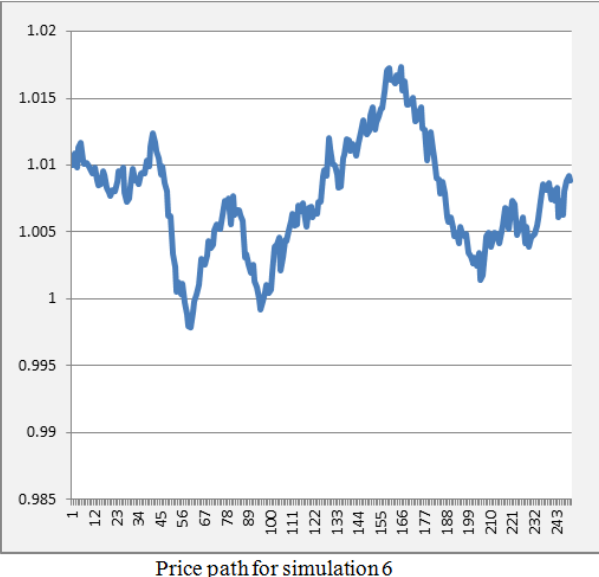

Figure 1. Brownian motion realization of some price paths for Calbank.

The expected stock price path $\mathbb{E}(S(t))$ is also shown in Figure 2.

(a)

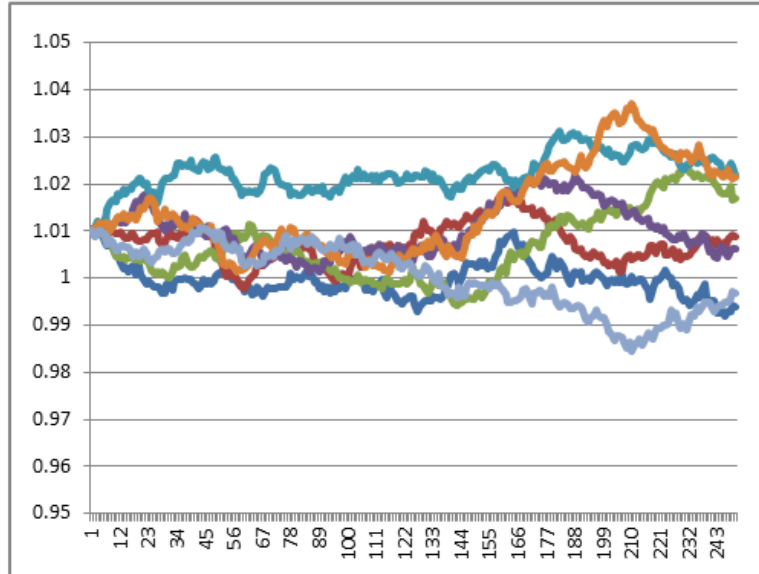

Combined price paths for CalBank (b)

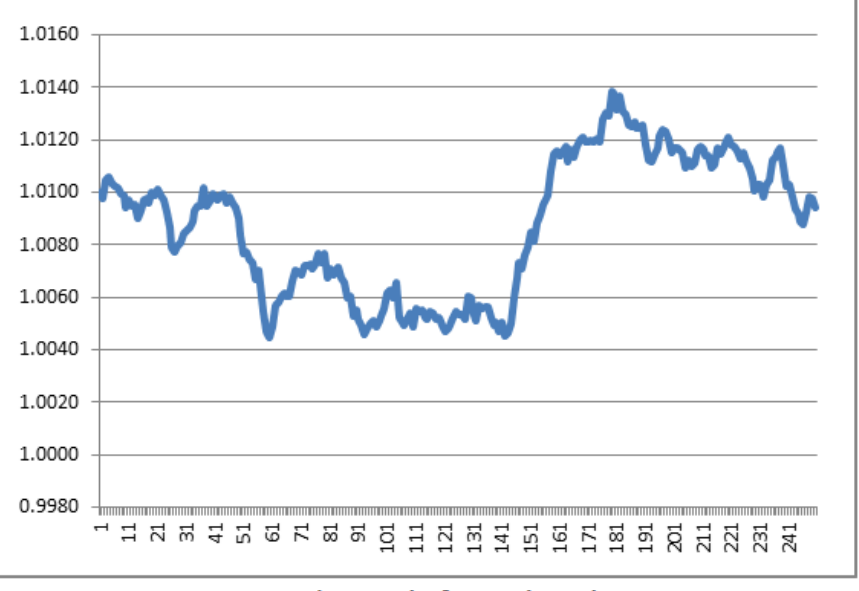

Mean price path for CalBank

Figure 2. Mean Brownian motion realization of price path of CalBank.

The simulation procedure is repeated for the all the stocks on GSE. The price paths, the daily returns and standard deviations of all stock for 2015 are obtained. Appendix A shows the simulation results of mean returns and standard deviations of all listed stocks.

\section{Discussion}

The Geometric Brownian Motion assumes that the stock price is lognormally distributed. This means that the logarithm of the stock price at time $t$ has a normal distribution with mean value $\mu t$ and variance $t \sigma^{2}$. The mathematical details are of vital interest and shall be examined. Let the stock price process follow the GBM

$$
d S(t)=\mu S(t) d t+\sigma S(t) \xi(t) d t .
$$

Let $f(t)=\operatorname{In} S(t)$, then $S(t)$ is an Ito process and using Ito formula gives

$d f(t)=\left(\mu S(t) \frac{\partial f}{\partial x}+\frac{\partial f}{\partial t}+\frac{1}{2} \sigma^{2} S^{2}(t) \frac{\partial^{2} f}{\partial x^{2}}\right) d t+\sigma S(t) \frac{\partial f}{\partial x} d B(t)(11)$
If $f(t)=\operatorname{InS}(t)$ then

$$
\frac{\partial f}{\partial x}=\frac{1}{S(t)}, \quad \frac{\partial f}{\partial t}=0, \quad \frac{\partial^{2} f}{\partial x^{2}}=-\frac{1}{S^{2}(t)}
$$

Substituting into Equation 7 it follows that

$$
\begin{gathered}
d f(t)=\left(\mu S(t) \frac{1}{S(t)}+0+\frac{1}{2} \sigma^{2} S^{2}(t)\left(-\frac{1}{X^{2}(t)}\right)\right) d t+\sigma S(t) \frac{1}{S(t)} d B(t) \\
d f(t)=\left(\mu-\frac{1}{2} \sigma^{2}\right) d t+\sigma d B(t)
\end{gathered}
$$

or

$$
\operatorname{dInS}(t)=\left(\mu-\frac{1}{2} \sigma^{2}\right) d t+\sigma d B(t)
$$

Equation 12 indicates that $f(t)$ follows an Ito process with mean rate $\left(\mu-\frac{1}{2} \sigma^{2}\right)$ and variance $\sigma^{2}$. Thus, the change in stock price between two future times $s$ and $t, s<t$ is normally distributed with mean rate $\left(\mu-\frac{1}{2} \sigma^{2}\right)(t-s)$ and 
variance $\sigma^{2}(t-s)$. If the initial time is 0 and the future time is $T$, then we can write

$$
\operatorname{InS}(T)-\operatorname{InS}(0) \sim N\left(\left(\mu-\frac{1}{2} \sigma^{2}\right) T, \sigma \sqrt{T}\right)
$$

or

$$
\operatorname{InS}(T) \sim N\left(\operatorname{InS}(0)+\left(\mu-\frac{1}{2} \sigma^{2}\right) T, \quad \sigma \sqrt{T}\right)
$$

Now if the stock price is lognormally distributed and knowing mean $\mu$, and volatility $\sigma$, the distribution of the stock and its density function can be determined to characterize the stock's future price behaviour.

Consider for example HFC Bank with initial stock price $S(0)=\varnothing 1.50$, with an annual return of $\mu=0.039$ and volatility $\sigma=0.22$. The price behaviour of the stock in the next 6 months can be established using equation

$$
\operatorname{InS}(T) \sim N\left(\operatorname{InS}(0)+\left(\mu-\frac{1}{2} \sigma^{2}\right) T, \sigma \sqrt{T}\right)
$$

That is

$$
\begin{gathered}
\operatorname{InS}(T) \sim N\left(\operatorname{In} 1.50+\left(0.039-\frac{1}{2}(0.22)^{2}\right) \times 0.5, \quad 0.22 \sqrt{0.5}\right) \\
\operatorname{InS}(T) \sim N(0.4055+0074, \quad 0.1555) \\
\operatorname{InS}(T) \sim N(0.4129, \quad 0.1555)
\end{gathered}
$$

A $95 \%$ confidence interval for the distribution of $\operatorname{InS}(T)$ in the next six months can be given as

$$
\begin{gathered}
\mu-1.96 \sigma<\operatorname{InS}(T)<\mu+1.96 \sigma \\
0.4129-1.96 \times 0.1555<\operatorname{InS}(T)<0.4129+1.96 \times 0.1555 \\
0.1080<\operatorname{InS}(T)<0.7178 \\
e^{0.1080}<S(T)<e^{0.7178} \\
1.114<S(T)<2.0499
\end{gathered}
$$

Thus there is $95 \%$ confidence that in the next six months HFC's stock will lie between $\varnothing 1.11$ and $\varnothing 2.05$. that is

$$
P(1.114<S(T)<2.0499)=0.95
$$

Now if a random variable is lognormally distributed then it density is given by

$$
f(x)=\frac{1}{x \sigma \sqrt{2 \pi}} e^{-(\operatorname{In} x-\mu)^{2}}, \quad x \geq 0
$$

and has a cumulative distribution function

$$
F(X)=\int_{-\infty}^{\infty} \frac{1}{x \sigma \sqrt{2 \pi}} e^{-(\operatorname{In} x-\mu)^{2}} d x
$$

If the random variable $X$ is the stock price $S(t)$ then we can write

$$
f(S(t))=\frac{1}{S(t) \sigma \sqrt{2 \pi}} e^{-(\operatorname{In} S(t)-\mu)^{2}}, \quad s \geq 0
$$

For HFC with $\mu=0.039$ and variance $\sigma=0.22$ and so its density function is given as

$$
f(S(t))=\frac{1}{0.22 S(t) \sqrt{2 \pi}} e^{-(\ln (S(t))-0.039)^{2}}
$$

The cumulative distribution function is given by

$$
F(S(t))=\int_{0}^{t} \frac{1}{0.22 s \sqrt{2 \pi}} e^{-(\ln (S)-0.0397)^{2}} d s
$$

Finally, to test the accuracy of our model, the simulated or predicted prices for 2015 are compared against the actual stock prices obtained in 2015. This is achieved by testing whether there is a significant difference $(\alpha=5 \%)$ between the daily mean returns of the stock price predicted by the model and the actual stock prices for 2015. The summary of the result is given in Appendix A. The results show that the model is able to predict accurately the price behaviour of more than $80 \%$ of the listed stocks.

From Appendix A, it is realised that when the average returns predicted by the model are compared to the actual average returns, there was no significant difference between the predicted and actuals in $29(82 \%)$ out of 35 traded stocks. There are several reasons why the model could not predict accurately in all cases. Firstly, the assumption was that the starting stock price for simulation of prices for 2015 will not be different from the last day trading price in 2014 can be problematic. This assumption has its own inherent drawbacks that could have significant effect on the simulation results if the two trading prices are significantly different. Future research and studies can possibly consider using the average stock price or the modal stock price for the previous year as $S_{0}$ for the coming year. Secondly, the volatility used for the simulation procedure was computed from the 2014 stock prices. More sophisticated approaches to estimating the volatility such as Exponentially Moving Average (EWMA), Autoregressive Conditional Heteroscedasticity (ARCH) and Generalized Autoregressive Conditional Heteroscedasticity (GARCH) exist and could be examined. Another alternative approach to estimate the volatility is the use of what is termed as implied volatility. This is the volatility implied by an option price observed in the market. Other important issue that must have accounted for the variation is the number of days used in computing the time intervals and estimating volatility parameters. There is academic argument on whether time should be measured in calendar days or trading days. Here trading days were used although interest rates and yield values are computed using calendar days. By using trading days, all days when the exchange is closed are ignored and for this a further assumption is made that volatility changes only when the exchange is opened. This could lead to slight errors in volatility estimates. However, in spite of these shortcomings the model is a good predictor and there is enough evidence here to suggest that it will be useful to investors, financial engineers, analyst and researchers. 


\section{Conclusions}

A model has been developed in the study to predict stock price behaviour and the model has subsequently been used to simulate stock behaviour using data from the Ghana Stock Exchange. The results of the simulated or forecasted prices were subsequently compared to the actual prices obtained.
The results show that the model consistently predicts stock behaviour in more than $80 \%$ of the cases. A procedure to mathematically examine the probabilistic distribution of stocks has also been provided. It is hoped that this work will help investors and other stakeholders especially on the stock market in Ghana to make informed decisions in regards to stock trading.

\section{Appendix}

Table A1. Predicted vrs actual returns of volatility of stocks listed on Ghana stock exchange.

\begin{tabular}{|c|c|c|c|c|c|c|c|c|}
\hline & \multicolumn{2}{|c|}{ African Champion Ltd } & \multicolumn{2}{|c|}{ AngloGold Ashanti Ltd. } & \multicolumn{2}{|c|}{ Aluworks Limited } & \multicolumn{2}{|c|}{ Ayrton Drug Manufacturing Ltd. } \\
\hline & Predicted & Actuals & Predicted & Actuals & Predicted & Actuals & Predicted & Actuals \\
\hline Mean Daily Returns & -0.0002458 & 0.00 & 0.00 & 0.00 & -0.00019 & 0.007878 & 0.00007 & -0.002 \\
\hline Variance & 0.00000122 & 0.0039 & 0.00 & 0.00 & 0.00000380 & 0.004641 & 0.000000227 & 0.0004 \\
\hline \multirow{3}{*}{$\begin{array}{l}\text { Test of Significance } \\
(\alpha=5 \%) \text { between means } \\
\text { Decision }\end{array}$} & critical value & 1.6511 & critical value & -1.6511 & critical value & 1.6511 & critical value & 1.6511 \\
\hline & test statistic & 0.3879 & test statistic & -1.534 & test statistic & & test statistic & 1.5868 \\
\hline & \multicolumn{2}{|c|}{ No significant difference } & \multicolumn{2}{|c|}{ No significant difference } & \multicolumn{2}{|c|}{ Significantly different } & \multicolumn{2}{|c|}{ No significant difference } \\
\hline & \multicolumn{2}{|c|}{ Benso Oil Palm Plantation } & \multirow{2}{*}{\multicolumn{2}{|c|}{$\begin{array}{l}\text { CalBank Ltd } \\
\text { Predicted }\end{array}$}} & \multicolumn{4}{|c|}{ Clydestone (Ghana) Ltd. } \\
\hline & Predicted & Actuals & & & Actuals & \multicolumn{2}{|c|}{ Predicted } & Actuals \\
\hline Mean Daily Returns & $7.13 \mathrm{E}-05$ & -0.002 & \multicolumn{2}{|c|}{-0.00013} & 0.025647 & \multicolumn{2}{|c|}{$-7.97 \mathrm{E}-06$} & 0 \\
\hline Variance & $2.27 \mathrm{E}-07$ & 0.0004 & \multicolumn{2}{|c|}{$2.43 \mathrm{E}-07$} & 0.0003 & \multicolumn{2}{|c|}{$1.35 \mathrm{E}-09$} & 0 \\
\hline Test of Significance & critical value & 1.651 & \multicolumn{2}{|c|}{ critical value } & 1.6511 & \multicolumn{2}{|c|}{ critical value } & 1.6511 \\
\hline$(\alpha=5 \%)$ between means & test statistic & 1.5868 & \multicolumn{2}{|c|}{ test statistic } & 0.07845 & & statistic & 1.285933 \\
\hline
\end{tabular}

\begin{tabular}{|c|c|c|c|c|c|c|c|c|}
\hline & \multicolumn{2}{|c|}{ Camelot Ghana Ltd. } & \multicolumn{2}{|c|}{ Cocoa Processing Co. Ltd. } & \multicolumn{2}{|c|}{ Ecobank Ghana Ltd. } & \multicolumn{2}{|c|}{ Enterprise Group Ltd. } \\
\hline & Predicted & Actuals & Predicted & Actuals & Predicted & Actuals & Predicted & Actuals \\
\hline Mean Daily Returns & -0.00036 & 0 & 0.0003947 & 0 & $-3.541 \mathrm{E}-06$ & -0.00033 & $-2.416 \mathrm{E}-05$ & 0.00128 \\
\hline Variance & $1.426 \mathrm{E}-07$ & 0 & $1.103 \mathrm{E}-05$ & 0.023437 & $1.365 \mathrm{E}-09$ & 0.000172 & $3.532 \mathrm{E}-07$ & 0.00018 \\
\hline Test of Significance & critical value & 1.6511 & critical value & 1.6511 & critical value & 1.6511 & critical value & 1.6511 \\
\hline$(\alpha=5 \%$ ) between means & test statistic & -4.41 & test statistic & 0.0405 & test statistic & 0.387857 & test statistic & -1.5338 \\
\hline Decision & \multicolumn{2}{|c|}{ No significant difference } & \multicolumn{2}{|c|}{ No significant difference } & \multicolumn{2}{|c|}{ No significant difference } & \multicolumn{2}{|c|}{ No significant difference } \\
\hline
\end{tabular}

\begin{tabular}{|c|c|c|c|c|c|c|}
\hline & \multicolumn{2}{|c|}{ Ecobank Transnational Inc. } & \multicolumn{2}{|c|}{ Fan Milk Ltd. } & \multicolumn{2}{|c|}{ Ghana Commercial Bank Ltd. } \\
\hline & Predicted & Actuals & Predicted & Actuals & Predicted & Actuals \\
\hline Mean Daily Returns & 0.000159 & $-1 \mathrm{E}-04$ & $-2.4 \mathrm{E}-06$ & 0.001362 & $-1.43 \mathrm{E}-05$ & -0.001737 \\
\hline Test of Significance & critical value & 1.651 & critical value & 1.6511 & critical value & 1.6511 \\
\hline$(\alpha=5 \%)$ between means & test statistic & 0.216 & test statistic & -2.69775 & test statistic & 3.801386 \\
\hline Decision & \multicolumn{4}{|c|}{ No significant difference } & \multicolumn{2}{|c|}{ Significantly different } \\
\hline
\end{tabular}

\begin{tabular}{|c|c|c|c|c|c|c|}
\hline & \multicolumn{2}{|c|}{ Guinness Ghana Breweries Ltd. } & \multicolumn{2}{|c|}{ Ghana Oil Company Ltd. } & \multicolumn{2}{|c|}{ Golden Star Resources Ltd. } \\
\hline & Predicted & Actuals & Predicted & Actuals & Predicted & Actuals \\
\hline Mean Daily Returns & -0.000155 & -0.00192 & 4.037E-05 & 0.001165 & $-8.316 \mathrm{E}-07$ & -0.00066 \\
\hline Variance & $3.06 \mathrm{E}-07$ & 0.00036 & $9.549 \mathrm{E}-08$ & 0.000153 & $3.9355 \mathrm{E}-10$ & 0.000106 \\
\hline \multirow{2}{*}{$\begin{array}{l}\text { Test of Significance ( } \alpha=5 \% \text { ) } \\
\text { between means }\end{array}$} & critical value & 1.6511 & critical value & 1.6511 & critical value & 1.6511 \\
\hline & test statistic & 1.44 & test statistic & -1.43 & test statistic & 0.99873 \\
\hline Decision & \multicolumn{2}{|c|}{ No significant difference } & \multicolumn{2}{|c|}{ No significant difference } & \multicolumn{2}{|c|}{ Significant difference } \\
\hline
\end{tabular}

\begin{tabular}{|c|c|c|c|c|c|c|c|c|}
\hline & \multicolumn{2}{|c|}{ Golden Web Ltd. } & \multicolumn{2}{|c|}{ HFC Bank (Ghana) Ltd. } & \multicolumn{2}{|c|}{ Mechanical Lloyd Co. Ltd. } & \multicolumn{2}{|c|}{ Pioneer Kitchenware Ltd. } \\
\hline & Predicted & Actuals & Predicted & Actuals & Predicted & Actuals & Predicted & Actuals \\
\hline Mean Daily Returns & $-2.683 \mathrm{E}-05$ & -0.00445 & 0.000108 & -0.002 & 0.000451 & -0.00157 & 0 & -0.000738 \\
\hline Test of Significance & critical value & 1.6511 & critical value & 1.651 & critical value & 1.6511 & critical value & 1.6511 \\
\hline$(\alpha=5 \%$ ) between means & test statistic & 1.36 & test statistic & 1.358 & test statistic & 1.252199 & test statistic & 1.0000 \\
\hline Decision & \multicolumn{2}{|c|}{ No significant difference } & \multicolumn{2}{|c|}{ No significant difference } & \multicolumn{2}{|c|}{ No significant difference } & \multicolumn{2}{|c|}{ No significant difference } \\
\hline
\end{tabular}




\begin{tabular}{|c|c|c|c|c|c|c|}
\hline & \multicolumn{2}{|c|}{ Produce Buying Company Ltd. } & \multicolumn{2}{|c|}{ PZ Cussons Ghana Ltd. } & \multicolumn{2}{|c|}{ Standard Chartered Bank Ghana. Ltd. } \\
\hline & Predicted & Actuals & Predicted & Actuals & Predicted & Actuals \\
\hline Mean Daily Returns & $-3.76 \mathrm{E}-05$ & -0.00074 & -0.000227 & 0.000507 & 0.00010518 & -0.0009 \\
\hline Variance & $6.536 \mathrm{E}-07$ & 0.00038 & 2.152E-07 & 0.000298 & $1.0604 \mathrm{E}-07$ & $3.95 \mathrm{E}-05$ \\
\hline Test of Significance & critical value & 1.6511 & critical value & 1.6511 & critical value & 1.6511 \\
\hline$(\alpha=5 \%)$ between means & test statistic & 0.56083 & test statistic & -0.66830 & test statistic & 2.504898 \\
\hline Decision & \multicolumn{2}{|c|}{ No significant difference } & \multicolumn{2}{|c|}{ No significant difference } & Significantly & \\
\hline
\end{tabular}

\begin{tabular}{|c|c|c|c|c|c|c|c|c|}
\hline & \multicolumn{2}{|c|}{ SIC Insurance Company Ltd. } & \multicolumn{2}{|c|}{ Starwin Products Ltd. } & \multicolumn{2}{|c|}{ Societe Generale Ghana Ltd. } & \multicolumn{2}{|c|}{ Sam Woode Ltd. } \\
\hline & Predicted & Actuals & Predicted & Actuals & Predicted & Actuals & Predicted & Actuals \\
\hline Mean Daily Returns & $-2.353 \mathrm{E}-05$ & -0.00393 & -0.000197 & 0.0028 & $4.04 \mathrm{E}-05$ & 0.001165 & 0.000701 & 0 \\
\hline Variance & $3.5539 \mathrm{E}-07$ & 0.00142 & 3.74E-06 & 0.0044 & $9.55 \mathrm{E}-08$ & 0.000153 & 7.42E-07 & 0 \\
\hline Test of Significance & critical value & 1.6511 & critical value & 1.651 & critical value & 1.6511 & critical value & 1.6511 \\
\hline$(\alpha=5 \%)$ between means & test statistic & 1.6326 & test statistic & -0.714 & test statistic & -1.42835 & test statistic & 2.145349 \\
\hline Decision & \multicolumn{2}{|c|}{ No significant difference } & \multicolumn{2}{|c|}{ No significant difference } & \multicolumn{2}{|c|}{ No significant difference } & \multicolumn{2}{|c|}{ Significantly different } \\
\hline
\end{tabular}

\begin{tabular}{|c|c|c|c|c|c|c|}
\hline & \multicolumn{2}{|c|}{ Trust Bank Ghana Ltd. } & \multicolumn{2}{|c|}{ Total Petroleum Ghana Ltd. } & \multicolumn{2}{|c|}{ Transaction Solutions (Ghana) Ltd. } \\
\hline & Predicted & Actuals & Predicted & Actuals & Predicted & Actuals \\
\hline Mean Daily Returns & $-7.74 \mathrm{E}-05$ & 0.00175 & $-1.11 \mathrm{E}-05$ & -0.00072 & 0.00000 & 0.00000 \\
\hline Variance & 4.096E-07 & 0.00024 & 4.449E-07 & 0.000205 & 0.00000 & 0.00000 \\
\hline Test of Significance & critical value & 1.6511 & critical value & 1.6511 & critical value & 1.6511 \\
\hline$(\alpha=5 \%)$ between means & test statistic & -1.84189 & test statistic & 0.67535 & test statistic & 0.00 \\
\hline Decision & \multicolumn{2}{|c|}{ No significant difference } & \multicolumn{2}{|c|}{ No significant difference } & \multicolumn{2}{|c|}{ No significant difference } \\
\hline
\end{tabular}

\begin{tabular}{|c|c|c|c|c|c|c|c|c|}
\hline & \multicolumn{2}{|c|}{ Tullow Oil PIc } & \multicolumn{2}{|c|}{ Unilever Ghana Ltd. } & \multicolumn{2}{|c|}{ UT Bank Ltd. } & \multicolumn{2}{|c|}{ Mega African Capital Ltd. } \\
\hline & Predicted & Actuals & Predicted & Actuals & Predicted & Actuals & Predicted & Actuals \\
\hline Mean Daily Returns & $-5.764 \mathrm{E}-05$ & -0.0009 & 0.000203 & $-9 \mathrm{E}-04$ & $-4.7 \mathrm{E}-05$ & -0.00371 & 0.000256 & 0.001165 \\
\hline Variance & 4.0789E-07 & 0.00012 & $2.43 \mathrm{E}-07$ & 0.0002 & $9.49 \mathrm{E}-07$ & 0.000915 & $1.81 \mathrm{E}-07$ & $8.14 \mathrm{E}-05$ \\
\hline Test of Significance & critical value & 1.6511 & critical value & 1.651 & critical value & 1.6511 & critical value & 1.6511 \\
\hline$(\alpha=5 \%)$ between means & test statistic & 1.22083 & test statistic & 0.9276 & test statistic & 1.905304 & test statistic & -1.366188 \\
\hline Decision & \multicolumn{2}{|c|}{ No significant difference } & \multicolumn{2}{|c|}{ No significant difference } & \multicolumn{2}{|c|}{ Significantly different } & \multicolumn{2}{|c|}{ No significant difference } \\
\hline
\end{tabular}

\section{References}

[1] Brown, R. (1828), A brief account of microscopical observations made on the particles contained in the pollen of plants, London and Edinburgh philosophical magazine and journal of science, 4, 161-173.

[2] A. Einstein, (1905), On the movement of small particles suspended in stationary liquids required by the molecularkinetic theory of heat, Annalen der Physik, 17, 549-560.

[3] N. Wiener, (1921), The average of an analytic functional and the Brownian movement, Proc. Natl. Acad. Sci. USA 7, 294 298.

[4] Bachelier, L. (1900), The'orie de la spe'culation, Annales Scientifiques de l'E'cole Normale Supe'rieure Se'r., 3(17), 21-86.

[5] Kendall, M. G. (1953), The analysis of economic time-series. Part I: Prices. Journal of the Royal Statistical Society 116, 1125.

[6] Roberts, H. V. (1959), Stock-market patterns and financial analysis: methodological suggestions. Journal of Finance, 14. 1, 1-10.

[7] Samuelson, P. A. (1965), Proof that properly anticipated prices fluctuate randomly, Industrial Management Review, 6(2), 4149.

[8] Fama, E. F. (1965), The behavior of stock-market prices. Journal of Business 38.1, 34-105.
[9] Fama, E. F. (1970), Efficient Capital Markets: A review of theory and empirical work. Journal of Finance, 25. 2, 383-417.

[10] Cootner, P. H. (1962), Stock prices: random vs. systematic changes. Industrial Management Review 3. 2, 24-45.

[11] Beja, A. (1977), The limits of price information in market processes, Working paper 61, University of California, Berkeley, Berkeley.

[12] Grossman, S. J., Stiglitz J. E. (1980), The impossibility of informationally efficient markets. American Economic Review, 70. 3, 393-407.

[13] Summers, L. H. (1986), Does the stock market rationally reflect fundamental values? The Journal of Finance, 41(3), 591-601.

[14] French, K. R. and Roll, R. (1986), Stock return variances: The arrival of information and the reaction of traders, Journal of Financial Economics 17(1), 5-26.

[15] Lo and MacKinlay (1988), Stock market do not follow random walks: evidence from a simple specification test, the review of financial studies, Vol 1. No. 1 (spring 1988) 41-66.

[16] Poterba and Summers, (1988), Mean reversion in stock prices, Journal of Financial Economics, Vol. 22, 27-59.

[17] Harvey, S. K. et al., (2008), Effect of exchange rate volatility on the Ghana Stock Exchange, African Journal of Accounting, Economics, Finance and Banking Research. 3(3): 28 - 47.

[18] Antwi S. et al., (2012), An empirical analysis of the performance of the Ghana stock exchange and treasury bills, International Journal of Business and Social Science Vol. 3 No. 23. 
[19] Osei V, (2005), Does the stock market matter in Ghana? A Granger-Causality Analysis (Research Dept.) Bank of Ghana.

[20] Mantas Landauskas, (2011), Modelling of stock prices by the Markov chain Monte Carlo method, Intellectual Economics., Vol. 5, no. 2(10), 244-256.

[21] Yoon, Y., Swales, G., (1991), Predicting stock price performance: A neural network approach. In: Proceedings of the 24th Hawaii International Conference on System Sciences., 4, 156-162.

[22] Refenes, A. N., Zapranis, A., Francis, G., (1994). Stock performance modeling using neural networks: A comparative study with regression models. Neural Networks, 7 (2), 375388 .

[23] Kryzanowski, L., Galler, M., Wright, D. W., (1993), Using artificial neural networks to pick stocks. Financial Analysts Journal, 21-27.

[24] Azoff, E. M., (1994), Neural Network Time Series Forecasting of Financial Markets. John Wiley and Sons, Chichester.
[25] Neenwi, S., Asagba, P. O., L. G. Kabari., (2013), Predicting the Nigerian stock market using artificial neural network European journal of computer science and information Vol. 1 No. 1, 30-39.

[26] Rene D. Estember, Michael John R. Maraña (2016), Forecasting of stock prices using brownian motion -Monte Carlo Simulation, Proceedings of the 2016 International Conference on Industrial Engineering and Operations Management Kuala Lumpur, Malaysia,

[27] Introduction to Stochastic Calculus with Applications (2005), Second Edition, Fima C. Klebener, Imperial College Press, 57 Shelton Street, Covent Garden, London WC2H 9HE.

[28] Walter A. Rosenkrantz, (2003), Why stock prices have a lognormal distribution, Department of Mathematics and Statistics, University of Massachusetts at Amhers.

[29] Hull John. C., (2006), Option, Futures and Other Derivatives, $6^{\text {th }}$ edition, Pearson Education Inc. Prentice Hall, Upper Sale River, New Jersey, 263-312. 